\title{
PENGARUH MEDIA TANAM TERHADAP PERTUMBUHAN SETEK MIKRO KENTANG VARIETAS GRANOLA (Solanum Tuberosum L)
}

\author{
EFRIANA JON \\ Sekolah Tinggi Keguruan dan Ilmu Pendidikan (STKIP) Muhammadiyah Sungai Penuh \\ E-mail :efrianajon86@gmail.com
}

\begin{abstract}
Potato (Solanum tuberosum L) isan agricultural crop that has high economic value, it gets priority to be developed. This research at wasconductedScreen House of Balai Benih Induk Kentang (BBIK) Kayu Aro subdistrict Kerinci regency.The purpose of this research was to know the effect of planting media On Micro Cutting Growth Of Granola Potato Variety (Solanum Tuberosum L). This study was used Completely Randomized Design (RAL) with 6 Treatment 10 Deuteronomy. The observed parameters were percentage of live micro cuttings potato, the high micro cuttings, number of shoots, numbr of leaves, and length of rootwere analyzed by the variance of investigation and followed by DNMRT advanced test at 5\% level. The investigation result of the highest percentage (\%)of micro cutting potato live was $90 \%$. The High of micro cuttings, number of shoots and number of leaves of micro cuttings granola varieties was showed that no significant effect on the treatment given. Whereas for the root length of micro cuttings showed thatthere was a significantly different effect.
\end{abstract}

Keywords :Potato (Solanum tuberosum L), micro cuttings,planting media.

\section{PENDAHULUAN}

Kentang (Solanum tuberosum L) merupakan tanaman pertanian yang mempunyai nilai ekonomi yang tinggi, sehingga mendapat prioritas untuk dikembangkan dan selanjutnya di ekspor. Disamping rasanya yang enak, kentang juga mempunyai nilai gizi yang cukup tinggi seperti karbohidrat, protein, lemak, kalori dan vitamin $\mathrm{C}$.

Kentang varietas granola merupakan salah satu varietas unggul yang sangat digemari oleh berbagai kalangan masyarakat. Varietas ini banyak digunakan sebagai bahan konsumsi rumah tangga maupun sebagai bahan baku industri makanan. Kentang varietas granola mempunyai potensi menghasilkan produksi yang tinggi apa bila dikembangkan dengan teknik yang benar. Varietas granola mempunyai banyak kelebihan antara lain tahan terhadap beberapa hama, penyakit dan virus.

Produksi kentang di Indonesia masih tergolong rendah. Menurut catatan FAO tahun 1993, produksi kentang di Indonesia baru mencapai 13, 333 ton/ha, sangat jauh tertinggal dibanding Jepang yang mencapai 31,667 ton/ha, Australia 29,098 ton/ha, dan New Zealand 27, 128 ton/ha (Soelarso, 2000).

Untuk mengatasi masalah ini, Indonesia terus melakukan perbaikan- 
perbaikan varietas, pengendalian hama dan penyakit serta perbaikan sistem pengadaan bibit. Cara-cara yang dikembangkan dewasa ini dengan menggunakan teknologi baru yang menunjang perbaikan pengembangan tanaman seperti penggunaan bibit botanis, kultur jaringan, teknik perbanyakan cepat melalui setek serta penggabungan cara-cara tersebut.

Alternatif teknik perbanyakan cepat pada tanaman kentang dapat dilakukan dengan menggabungkan teknik hasil kultur jaringan yang selanjutnya disetek mikro. Keuntungan dari teknik tersebut yaitu dapat menyediakan jumlah bibit yang lebih banyak dalam waktu yang singkat, bebas pathogen, tidak merusak tanaman induk dan tidak tergantung musim (Gunawan, 2003).

Salah satu tahapan dalam aplikasi hasil kultur jaringan yang sudah di setek mikro terdapat tahapan proses aklimatisasi yaitu tahapan pada masa penyesuaian tanaman dengan lingkungan baru. Faktor aklimatisasi sangat dipengaruhi oleh media tanam yang digunakan, karena tidak semua media tanam dapat menjamin keberhasilan aklimatisasi yang sangat rentan terhadap berbagai faktor penghambat pertumbuhan tanaman.

Menurut Supriadi dan Rukmana (2002), media untuk pertumbuhan setek mikro kentang varietas granola (Solanum tuberosumL) sangat banyak didapatkan di lingkungan masyarakat seperti pemanfaatan dari limbah pertanian dan limbah industri, limbah ini dapat diolah menjadi pupuk organik yang dapat menunjang pertumbuhan serta perkembangan tanaman kentang hasil setek mikro. Untuk media pembibitan yang baik dibutuhkan media yang mempunyai sifat fisik yang baik. salah satunya yaitu bahan organik yang dapat dipakai berasal dari pupuk kandang, pupuk hijau, arang sekam, kompos dan gambut.
Kurang termanfaatnya pupuk organik saat ini menjadi masalah bagi kesuburan tanah dikarenakan masyarakat yang sudah sangat ketergantungan dengan pupuk buatan yang mengandung zat-zat kimia yang tinggi, sehingga berdampak negatif terhadap lingkungan terutama pencemaran lahan tanaman kentang yang mengakibatkan lahan tanaman tandus dan stress sehingga tanaman sukar berkembang dengan baik, dan juga gangguan terhadap kesehatan.

Hal inilah yang menyebabkan semakin rendahnya produksi kentang karena tidak adanya keseimbangan alam antara lahan dan tanaman pertanian.

Solusi yang tepat untuk mengatasi hal ini adalah dengan memanfaatkan bahan organic tersebut dengan cara mencampur pupuk organik dengan tanah menggunakan volume agar media yang dihasilkan seimbang untuk pertumbuhan terutama bagi tanaman kentang hasil setek mikro.

Media tanam juga memerlukan faktor pendukung yaitu screen house untuk melindungi tanaman dari binatang liar penyebar virus yang kecil sekalipun sehingga untuk lebih mempermudah perkembangan bibit kentang PEMDA Kecamatan Kayu Aro Kabupaten Kerinci membangun Balai Benih induk Kentang (BBIK).

Tujuan penelitian ini adalah untuk mengetahui pengaruh media tanam terhadap pertumbuhan setek mikro kentang varietas granola (Solanum tuberosumL).

\section{METODE PENELITIAN}

Bahan yang digunakan dalam penelitian ini adalah bahan tanaman hasil setek dari planlet hasil kultur jaringan kentang varietas granola, tanah, pupuk kandang dari kotoran sapi, tanahgambut, arang sekam, rapid rood. Alat-alat yang digunakan adalah cangkul, ayakan pasir, drum pembakar, hand sprayer, gunting, 
skapel, kertas label ember, karung putih, plastik penyungkup, alat ukur, timbangan, kamera, polibag ukuran $1 \mathrm{~kg}$ dan peralatan tulis.

Penelitian ini menggunakan metode eksperimen yang disusun dalam Rancangan Acak Lengkap (RAL) dengan 6 perlakuan dan 10 ulangan. Seluruh percobaan terdiri dari 60 polibag dan tiap polibag terdiri dari 1 tanaman. Masing-masing perlakuan dalam percobaan ini adalah: $\mathrm{A}=$ Tanah + pasir + arang sekam (1:1:1), B = Tanah + pasir + pupuk kandang sapi $(1: 1: 1), \mathrm{C}=$ Tanah + tanah gambut + pasir $(1: 2: 1), \mathrm{D}=$ Tanah + tanah gambut + pupuk kandang sapi $(1: 1: 1)$, $\mathrm{E}=$ Tanah + arang sekam + pupuk kandang sapi (1:1:1), dan $F=$ Tanah. Penelitian terdiri dari beberapa tahap pelaksanaannya di lapangan yaitu persiapan media tanam, persiapan bahan tanam, dan pemeliharaan.

Pada persiapan media tanam, terlebih dahulu disterilkan dengan uap panas selama 2 jam. Tanah steril didiamkan selama satu malam. Sebelum dimasukkan ke dalam polibag masing-masing bahan media tanam dicampur aduk sesuai dengan perbandingan volume media tanam. Setiap polibag dipasang label sesuai dengan perlakuan percobaan untuk mempermudah dalam pengamatan.

Bahan tanam yang digunakan adalah setek pucuk yang berasal dari tanaman kentang hasil kultur jaringan yang berumur 8 minggu.

Setek pucuk yang diambil sebanyak 4 $\mathrm{cm}$, setek sebelum ditanam dalam polibag dicelupkan kedalam larutan rapid rood yang berguna untuk merangsang pertumbuhan akar.

Pemeliharaan yang utama adalah penyiraman, pemupukan, penyisipan, penyiangan dan pengendalian hama serta penyakit. Penyiraman dilakukan 1-2 kali sehari, tergantung keadaan cuaca yang jadi pedoman adalah kondisi media harus selalu lembab. Parameter yang diamati dalam penelitian ini meliputi persentase setek mikro yang hidup (\%), tinggi tanaman (cm), jumlah tunas, jumlah helaian daun, panjang akar.

Data yang diperoleh dianalisis secara statistik dengan uji F. jika F hitung besar dari F tabel $5 \%$ dilanjutkan dengan uji lanjutan Duncan's New Multiple Range Test (DNMRT) pada taraf nyata 5\%.

\section{HASIL DAN PEMBAHASAN}

Dari penelitian yang telah dilakukan, diperoleh hasil sebagai berikut:

1. Persentase Setek Mikro yang Hidup (\%)

Dari rata-rata persentase setek mikro yang hidup di peroleh hasil perlakuan media tanam $\mathrm{C}=$ Tanah + Tanah gambut + Pasir (1:2:1) menunjukkan persentase setek mikro yang hidup lebih tinggi dibandingkan dengan media lain. Sedangkan pada perlakuan media tanam A $=$ tanah + pasir + arang sekam $(1: 1: 1)$ mempunyai persentase setek mikro yang hidup terendah dibandingkan perlakuan media lainnya.

Tabel 1. Rata-rata persentase (\%) setek mikro tanaman kentang varietas granola yang hidup pada masing-masing perlakuan pada minggu ke-6

\begin{tabular}{|l|c|}
\hline \multicolumn{1}{|c|}{ Perlakuan } & Rata-rata persentase (\%) setek mikro yang hidup \\
\hline $\mathrm{A}=$ Tanah + pasir + arang sekam $(1: 1: 1)$, & 50 \\
\hline $\mathrm{D}=$ Tanah + tanah gambut + pupuk kandang sapi(1:1:1), & 60 \\
\hline E = Tanah + arang sekam + pupuk kandang sapi $(1: 1: 1)$, & 60 \\
\hline $\mathrm{F}=$ Tanah. & 60 \\
\hline $\mathrm{B}=$ Tanah + pasir + pupuk kandang sapi $(1: 1: 1)$, & 70 \\
\hline $\mathrm{C}=$ Tanah + tanah gambut + pasir $(1: 2: 1)$, & 90 \\
\hline
\end{tabular}

Keterangan: Angka-angka pada lajut di atas berbeda tidak nyata menurut uji $\mathrm{F}$ pada taraf nyata $5 \%$ 
Dari tabel 1 di atas dapat dilihat bahwa persentase setek mikro yang hidup menunjukkan pengaruh yang tidak berbeda nyata terhadap media tanam yang digunakan pada tahap aklimatisasi. Hal ini disebabkan karena unsur-unsur hara yang terkandul dalam media tanam belum dapat digunakan sepenuhnya untuk awal pertumbuhan setek mikro. Hasil kultur jaringan kentang varietas granola yang selanjunya disetek mikro pada proses awal pertumbuhannya masih mengandalkan kandungan unsur-unsur hara terutama air yang tersimpan di dalam sel-sel tanaman setek mikro, sehingga perbedaan komposisi media tersebut berpengaruh terhadap keberhasilan pertumbuhan setek mikro.

Hal ini didukung oleh pendapat Fitter dan Hay bahwa air adalah komponen utama tanaman hijau. Kebanyakan tanaman tak berkayu sebagian besar air dikandung dalam isi sel (85-90\%). Hal ini tentunya berdampak terhadap tanaman setek kentang dimana mekanisme kompetisi hara terutama air dan interaksinya, tidak berlangsung dengan baik.

Perlakuan media tanam $\mathrm{C}$ lebih baik karena adanya campuran tanah + gambut + pasir (1:2:1). Gambut ini sebagian besar terdiri dari sisa tanaman yang telah melapuk. Jika proses pelapukannya telah sempurna, maka akan menghasilkan sifat fisika tanah yang sangat menguntungkan. Hal ini berhubungan erat dengan kandungan air dan sirkulasi udara tanah serta dapat menyediakan unsure hara salah satunya unsur $\mathrm{P}$ (fosfor) bagi tanaman setek lebih banyak berfungsi untuk merangsang pertumbuhan seluruh pertumbuhan setek, khususnya batang dan cabang tanaman muda yang baru dipotong (disetek). Disamping faktor setek tanaman, faktor lingkungan meliputi kesuburan tanah berupa kandungan bahan organi dan faktor pelaksanaannya meliputi cara pemberian perlakuan. Ketiga faktor tersebut merupakan satu kesatuan yang saling berpengaruh (Anonimus, 2007).

Menurut Darmawijaya (2000), dimana tanah gambut merupakan bahan organik yang terdiri dari akumulasi sisa-sisa vegetasi yang mengalami humifikasi tetapi belum mengalami mineralisasi. Dalam hal ini endapan yang terbentuk mengalami dekomposisi dalam keadaan anaerob. Laju pertumbuhan bahan organik lebih cepat dan lebih tinggi dari laju dekomposisinya, menyebabkan kandungan bahan organik berada dalam persentase yang sangat tinggi, hal ini tentunya berpengaruh terhadap tekstur dan struktur tanah, merangsang pertumbuhan jumlah akar serta distribusi pori antara media tanam dan setek mikro.

Media pasir dan tanah pada media tanam $\mathrm{C}$ disamping gambut, mampu berinteraksi dengan baik bagi pertumbuhan setek mikro tanaman kentang disebabkan karena setek mikro hanya mau tumbuh dan produktif pada jenis tanah ringan yang mengandung sedikit pasir dan kaya bahan organik. Contohnya, tanah andosol (vulkanik) yang mengandung abu gunung berapi dengan tanah lempung berpasir. Jenis tanah mempengaruhi kandungan karbohidrat pada setek mikro tanaman kentang. Pada umumnya tanaman kentang yang dikembangkan di tanah berlempung mempunyai kandungan karbohidrat lebih tinggi dan rasanya lebih enak. Sedangkan pada media tanam $\mathrm{D}, \mathrm{E}, \mathrm{F}$ dan $\mathrm{B}$ mempunyai persentase setek mikro yang hidup relatif sama. Hal ini disebabkan 
karena kombinasi media tanam pada masing-masing perlakuan tidak berbeda, dan interaksi keempat media tanam tersebut dengan setek mikro belum memiliki daya aktif yang cukup.

2. Tinggi Setek Mikro Tanaman Kentang (cm)

Perlakuan media tanam A, B, E dan F menunjukkan pengaruh yang sama terhadap tinggi setek mikro tanaman kentang dan tidak berbeda nyata dengan media tanam C dan D. Dapat dilihat pada rata-rata tinggi setek mikro tanaman kentang setelah berumur 6 minggu pada Tabel 2 berikut:

Tabel 2. Tinggi setek mikro tanaman kentang $(\mathrm{cm})$ pada masing-masing perlakuan setelah berumur 6 minggu.

\begin{tabular}{|l|c|}
\multicolumn{1}{|c|}{ Perlakuan } & $\begin{array}{c}\text { Rata-rata Tinggi setek mikro } \\
\text { tanaman kentang }(\mathrm{cm})\end{array}$ \\
\hline $\mathrm{A}=$ Tanah + pasir + arang sekam $(1: 1: 1)$, & 4,1 \\
\hline $\mathrm{B}=$ Tanah + pasir + pupuk kandang sapi $(1: 1: 1)$, & 4,0 \\
\hline $\mathrm{C}$ = Tanah + tanah gambut + pasir $(1: 2: 1)$, & 5,4 \\
\hline $\mathrm{D}=$ Tanah + tanah gambut + pupuk kandang sapi $(1: 1: 1)$ & 5,2 \\
\hline $\mathrm{E}$ = Tanah + arang sekam + pupuk kandang sapi $(1: 1: 1)$, & 3,9 \\
\hline $\mathrm{F}$ = Tanah. & 4,5 \\
\hline
\end{tabular}

Keterangan: Angka-angka pada lajut di atas berbeda tidak nyata menurut uji $\mathrm{F}$ pada taraf nyata 5\%

Dari data di atas tinggi setek mikro tanaman kentang menunjukkan bahwa sifat fisik media tanam yang telah digunakan pada masing-masing perlakuan di atas tidak memberikan pengaruh yang nyata terhadap tinggi setek mikro tanaman kentang. Media tanam yang digunakan tersebut cenderung memperlihatkan pertumbuhan yang seragam terhadap tinggi setek mikro yang dihasilkan, diduga karena media tanam telah mengandung bahan organik yang cukup bagi pertumbuhan setek mikro tanaman kentang. Terutama unsur hara nitrogen (N) yang berfungsi untuk merangsang pertumbuhan tanaman secara menyeluruh, terutama batang dan cabang yang berkaitan erat dengan tinggi tanaman setek mikro.

Bahan organik sangat penting dalam menyediakan zat-zat hara bagi pertumbuhan tanaman terutama yang berasal dari pupuk kandang. Unsur kimia yang terkandung dalam tanah gambut juga mempunyai peranan penting terhadap pertumbuhan tinggi setek mikro tanaman kentang, seperti keasaman tanah, ketersediaan hara tanah, kapasitas tukar kation, kadar abu, dan kadar pirit atau sulfur, penting dalam penentuan komoditas perkembangan tanaman dan unsure nitrogen $(\mathrm{N})$ yang terkandung pada tanah gambut relatif lebih tinggi, sangat bagus apabila media tersebut digunakan untuk mempercepat pertumbuhan tinggi tanaman (Noor, 2001).

Udara mengisi rongga-rongga yang berada disela-sela partikel, hal ini sesuai dengan kemampuan pasir dan arang sekam dalam menjaga sirkulasi udara dalam tanah dan mempertahankan kandungan air juga di dalam media. Dengan demikian air dapat membawa unsur-unsur hara berupa ion-ion makanan yang dibutuhkan tanaman kedaerah perakaran bagian atas dan memudahkan pengisapan unsure-unsur hara tersebut pada akar serta penyebarannya melalui batang. Unsure-unsur hara yang cukup dan seimbang akan merangsang aktifitas 
fotosintesis dan sintesa karbohidrat, sehingga laju pertumbuhan tinggi tanaman akan lebih baik.

3. Jumlah Tunas Setek Mikro Tanaman Kentang Jumlah tunas setek mikro tanaman kentang (SolanumTuberosum L.) yang tumbuh diamati pada akhir

penelitian yaitu setelah setek mikro tanaman kentang berumur 6 minggu. Dari pengujian dengan sidik ragam terhadap jumlah tunas memperlihatkan bahwa penggunaan beberapa media memberikan pengaruh yang tidak berbeda nyata terhadap pertumbuhan tunas.

Tabel 3. Rata-rata jumlah tunas setek mikro tanaman kentang pada masing-masing perlakuan setelah minggu ke- 6 .

\begin{tabular}{|l|c|}
\hline \multicolumn{1}{|c|}{ Perlakuan } & Rata-rata \\
\hline A = Tanah + pasir + arang sekam $(1: 1: 1)$, & 3,4 \\
\hline B = Tanah + pasir + pupuk kandang sapi $(1: 1: 1)$, & 3,4 \\
\hline C = Tanah + tanah gambut + pasir $(1: 2: 1)$, & 3,8 \\
\hline D = Tanah + tanah gambut + pupuk kandang sapi $(1: 1: 1)$ & 3,5 \\
\hline E = Tanah + arang sekam + pupuk kandang sapi $(1: 1: 1)$, & 3,5 \\
\hline F = Tanah. & 3,5 \\
\hline
\end{tabular}

Dari tabel pengamatan jumlah tunas di atas menunjukkan bahwa perlakuan media tanam memberikan pengaruh yang tidak berbeda nyata terhadap jumlah tunas. Berpengaruh tidak nyata jumlah setek mikro disebabkan oleh media tanam yang belum terolah dengan sempurna dan daya serap akar untuk penyerapan unsur hara yang diperlukan untuk pertumbuhan jumlah tunas setek mikro seperti auksin yang terkandung pada media tanam menyebabkan auksin belum bekerja dengan baik untuk merangsang pertumbuhan tunas setek mikro.

Anonimus (2007), pemotongan tunas pucuk dari tanaman induk akan merangsang pertumbuhan tunas samping dari batang utama pada tiaptiap ketiak daun. Pemotongan tunas pucuk pada tanaman akan menghilangkan dominansi apical sehingga akan merangsang tumbuhnya tunas-tunas samping. Tetapi hal ini, tidak terlepas dari kandungan unsur hara pada media tanam yang mampu menunjang pertumbuhan jumlah tunas.

4. Jumlah Helaian Daun Setek Mikro Tanaman Kentang

Hasil pengujian dengan sidik ragam terhadap jumlah helaian daun setek mikro tanaman kentang memperlihatkan bahwa penggunaan berbagai media memberikan pengaruh yang tidak berbeda nyata terhadap jumlah helaian daun setek mikro tanaman kentang.

Tabel 4. Rata-rata Jumlah Helaian Daun Setek Mikro Tanaman Kentang pada masing-masing perlakuan setelah minggu ke-6.

\begin{tabular}{|l|c|}
\hline \multicolumn{1}{|c|}{ Perlakuan } & Rata-rata \\
\hline $\mathrm{A}=$ Tanah + pasir + arang sekam $(1: 1: 1)$, & 2,8 \\
\hline $\mathrm{B}=$ Tanah + pasir + pupuk kandang sapi $(1: 1: 1)$, & 2,8 \\
\hline $\mathrm{C}=$ Tanah + tanah gambut + pasir $(1: 2: 1)$, & 2,4 \\
\hline $\mathrm{D}=$ Tanah + tanah gambut + pupuk kandang sapi $(1: 1: 1)$ & 2,5 \\
\hline $\mathrm{E}=$ Tanah + arang sekam + pupuk kandang sapi $(1: 1: 1)$, & 2,8 \\
\hline $\mathrm{F}=$ Tanah. & 2,8 \\
\hline
\end{tabular}

Dari tabel di atas hasil pengamatan jumlah helaian daun setek mikro memperlihatkan tidak berbeda nyata terhadap perlakuan media tanam yang 
diberikan. Hal ini, disebabkan peranan dari media tanam yang kurang mampu untuk berinteraksi dengan akar tanaman setek mikro dalam mengolah unsure hara yang diperlukan untuk pertumbuhan daun, serta kemampuan setek mikro untuk menyerap bahan organic yang tersimpang dalam media tanam tersebut. Salah satunya yaitu unsure kalium (K) yang bermanfaat untuk membantu pembentukan protein dan karbohidrat, unsur ini akan memperkuat dan mempercepat pertumbuhan tanaman terutama daun sehingga tidak mudah gugur dan melancarkan proses transpirasi. Disamping itu, unsure hara yang diserap oleh setek mikro lebih banyak dialokasikan pada pertumbuhan luas daun dibandingkan jumlah daun setek pada saat pengamatan.

5. Panjang Akar Setek Mikro Tanaman Kentang

Hasil pengujian dengan sidik ragam terhadap panjang akar setek mikro tanaman kentang memperlihatkan bahwa penggunaan beberapa media memberikan pengaruh yang berbeda nyata pada rata-rata panjang akar setek mikro tanaman kentang.

Tabel 5. Rata-rata Panjang Akar Setek Mikro Tanaman Kentang pada masing-masing perlakuan setelah minggu ke-6

\begin{tabular}{|l|c|}
\hline \multicolumn{1}{|c|}{ Perlakuan } & Rata-rata \\
\hline $\mathrm{E}=$ Tanah + arang sekam + pupuk kandang sapi $(1: 1: 1)$, & 9 \\
\hline $\mathrm{A}=$ Tanah + pasir + arang sekam $(1: 1: 1)$, & $6,9 \mathrm{~b}$ \\
\hline $\mathrm{B}=$ Tanah + pasir + pupuk kandang sapi $(1: 1: 1)$, & $6,5 \mathrm{bc}$ \\
\hline $\mathrm{F}=$ Tanah. & $5,8 \mathrm{bc}$ \\
\hline $\mathrm{D}=$ Tanah + tanah gambut + pupuk kandang sapi $(1: 1: 1)$ & $5,5 \mathrm{c}$ \\
\hline $\mathrm{C}=$ Tanah + tanah gambut + pasir $(1: 2: 1)$, & $5,2 \mathrm{c}$ \\
\hline
\end{tabular}

Dari tabel di atas media tanamAberbedanyatadenganperlakuan media tanam $E$ dan $C$. Hal ini disebabkan karena komposisi media tanam yang digunakan telah mencukupi akan unsure hara yang diperlukan terutama bagi pertumbuhan panjang akar.

\section{SIMPULAN DAN SARAN}

Dari penelitian yang telah dilakukan maka dapat ditarik kesimpulan bahwa:

1. Media tanam yang diberikan berpengaruh nyata terhadap panjang akar tanaman kentang varietas granola pada akhir pengamatan

2. Hasil media tanam yang baik di dapatkan pada perlakuan tanah + arang sekam + pupuk kandang dengan perbandingan $(1: 1: 1)$

3. Sedangkan untuk presentase setek mikro yang hidup, tinggi setek, jumlah tunas dan jumlah helaian daun, memperlihatkan pengaruh yang tidak berbeda nyata terhadap perlakuan media tanam yang diberikan.

Disarankan untuk menggunakan media tanah + arang sekam + pupuk kandang dengan perbandingan (1:1:1) untuk pertumbuhan setek mikro kentangv arietas granola (Solanum Tuberosum L.). 
Vol. 3, No. 1 : Hal 26-33

Februari 2018

\section{RUJUKAN}

Anonimus, 2007. Kunci Sukses

Memperbanyak Tanaman. Jakarta

: Agromedia Pustaka.

Darmawijaya, 2000. Klasifikasi Tanah

Dasar dan Teori Bagi Penelitian

Tanah dari Pelaksanaan

pertanian Di Indonesia.

Yogyakarta: Gadjah Mada

University.

Gunawan, 2003. Teknik Kultur Jaringan Tumbuhan. Bogor: PAU Bioteknologi IPB
Noor, 2001. Pertanian Lahan Gambut

Potensi dan Kendala. Yogyakarta : Kanisius.

Soelarso, 2000. Budidaya Kentang Bebas Penyakit. Yogyakarta : Kanisius.

Supriadi dan Rukmana (2002), pengkajian dan penyimpanan gambut obrogen dalam rangka pemanfaatannya sebagai media semai. Pekan Baru: Departemen Kehutanan. 